\title{
Ecological Analysis of Acari Recovered from Coprolites from Archaeological Site of Northeast Brazil
}

\author{
Rita de Maria Seabra Nogueira de Candanedo Guerra/ ${ }^{+}$, Gilberto Salles Gazêta*, \\ Marinete Amorim*, Antonio Nascimento Duarte**, Nicolau Maués Serra-Freire*
}

\begin{abstract}
Laboratório de Parasitologia, Departamento de Patologia, Universidade Estadual do Maranhão, Cidade Universitária Paulo IV, Caixa Postal 09, 65055-970 São Luis, MA, Brasil *Laboratório de Ixodides, Departamento de Entomologia, Instituto Oswaldo Cruz-Fiocruz, Rio de Janeiro, RJ, Brasil **Laboratório de Paleoparasitologia, Escola Nacional de Saúde Pública-Fiocruz, Rio de Janeiro, RJ, Brasil
\end{abstract}

Coprolite samples of human and animal origin from the excavations performed at the archaeological site of Furna do Estrago, at Brejo da Madre de Deus in the state of Pernambuco, Brazil and sent to the Paleoparasitology Laboratory at Escola Nacional de Saúde Pública-Fiocruz, Rio de Janeiro, were analyzed for mites. After rehydratation and sedimentation of the coprolites, the alimentary contents and the sediments were examined and the mites collected and prepared in definitive whole mounts, using Hoyer's medium. Mites of the following suborders and orders were recovered: suborder Acaridia; order Gamasida; order Ixodida with the familiy Ixodidae (Ixodes sp. and Amblyomma sp. larvae, scutum, idiosoma, gnathosoma); order Oribatida (Aphelacarus sp., Apolohmannia sp., Eophypochthonius $s p$., Cosmochthonius $s p$., Pterobates $s p$., Poronoticae with pteromorphae not auriculate); order Astigmata with the families Atopomelidae (Chirodiscoides caviae), Anoetidae hypopus, Acaridae (Suidasia pontifica), Glycyphagidae (Blomia tropicalis), Pyroglyphidae (Hirstia passericola); order Actinedida with the family Tarsonemidae (Iponemus radiatae). The present work discusses the possibility of the preservation of the mite groups found up to the present day. We also discuss their relationship with the environment and their importance to present populations.

Key words: mite - paleoparasitology - coprolite - Northeast Brazil

Although helminths are reported frequently in paleoparasitolology, arthropods remains also preserve in archaeological deposits and can be studied. A remarkable aspect of these investigations has been the discovery of insect remains parasitic on humans, especially the flea Pulex irritans L. (Buckland \& Sadler 1989, Sadler 1990), the louse Pediculus L. (Ewing 1924, Horne 1979, Bresciani et al. 1983, Mumcuoglu \& Zias 1988, Sadler 1990, Araújo et al. 2000, Rick et al. 2001), and more rarely the pubic louse, Pthirus pubis L. (Girling 1984, Kenward 1999, Rick et al. 2001). Records of insect parasites of animals have rarely been documented in the scientific literature and refer to the finding of the lice Bovicola ovis (Schrank, 1781) (Sadler 1990), Microthoracius proelongyceps (Neumann, 1909) and M. minor Werneck, 1935 (Astos et al. 1999), Felicola felis (Werneck) 1934 (Guerra et al. 2001b), the hippoboscids Melophagus ovinus L. (Sadler 1990) and Lipoptena cervi L. (Gothe \& Schöl 1994).

The Acari are ancient arthropods and the earliest record of this group dates from the Devonian age (Krantz 1978). The oldest fossil mite recorded is Protacarus crani Hirst, 1923. Many orders of the subclass Acari are represented in fossil records from the Paleozoic, Mesozoic and Cenozoic epoch, such as Holothyrida, Gamasida,

$\overline{{ }^{+} \text {Corresponding author. Fax }}$ +55-98-245.2833. E-mail: grita62@hotmail.com

Received 26 August 2002

Accepted 25 November 2002
Oribatida, Astigmata, Actinedida, and Ixodida (Krivolusky \& Druk 1986, Woolley 1988). The order Ixodida includes the following records: Ixodes tertiarius (Scudder 1885 cited by Lane \& Poinar 1986); Ixodes succineus (Weidner \& Zecke 1964 cited by Lane \& Poinar 1986); Dermacentor reticulates (Schille 1916 cited by Lane \& Poinar 1986); Amblyomma similar to A. testudines (Lane \& Poinar 1986) and Ornithodoros antiquus (Poinar 1995).

Mites of the families Anoetidae, Acaridae and Lardoglyphidae were recovered from human coprolites and mummified remains in Nevada (Radovsky 1970). Kliks (1988) observed numerous specimens of saprophytic astigmatic mites in fecal material from Amerindian mummies. In Brazil there are few reports of Acari in paleoparasito-logical studies. Araújo et al. (1986) found mites of the family Cheyletidae in hair fragments and tissues of a mummified body. Guerra et al. (2001a) presented preliminary results of the finding of ixodid ticks and mites of the families Tarsonemidae, Atopomelidae, Glycyphagidae, Scutacaridae, Demodecidae and of the order oribatida, in coprolites.

Studies of arthropods preserved in archaeological deposits can provide information about past human economy, resource exploitation, diet, activity and living conditions as well as about the fauna. Radovsky (1970) states that besides the supply of additional material for systematic studies, the resulting comparative data on the Acari fauna after an extended interval could be of value to the anthropologists, climatologists, and acarologists. Possible human and animal health hazards can be foreseen through these investigations since some species of Acari are able to carry and transmit bioagents. 
The purpose of this paper is to discuss the finding of members of the subclass Acari in coprolites, supposing that further studies in this field will allow a better understanding of mites and ticks and their relationship with the environment and their hosts.

\section{MATERIALS AND METHODS}

Excavations were performed at the state of Pernambuco, Brazilian Northeast, in the archaeological site of Furna do Estrago ( $8^{\circ} 11^{\prime} 36^{\prime}$ 'S $\left.36^{\circ} 20^{\prime} 14^{\prime \prime} \mathrm{W}\right)$, in Brejo da Madre de Deus municipal district, by the staff of the Universidade Católica de Pernambuco. This site consists in a rock granite shelter composed of a single chamber of $125.10 \mathrm{~m}^{2}$, with an opening measuring $19 \mathrm{~m}$, maximum height of $4.80 \mathrm{~m}$, and depth of $8.80 \mathrm{~m}$. It was occupied by hunters-gatherers corresponding to different periods, dated to $11,060 \pm 90 \mathrm{yr} \mathrm{BP}, 9,150 \pm 50 \mathrm{yr}$ $\mathrm{BP}$, and 8,495 $\pm 70 \mathrm{yr}$ BP Intercepting this assemblage there is a more recent pre-historic occupation, when the shelter was used as a cemetery, dated to $1,860 \pm 50$ $\mathrm{yr} \mathrm{BP}, 1,730 \pm 70 \mathrm{yr} B P$, and $1,610 \pm 70 \mathrm{yr} \mathrm{BP}\left(\mathrm{C}^{14}\right.$ Smithsonian Institution). Dating was obtained from hearths and human bones (Lima 1991).

A total of 209 coprolites were collected and sent to the laboratory of Paleoparasitology, at Escola Nacional de Saúde Pública-Fiocruz, where their zoological identification was made. The zoological origin of the coprolites was obtained by comparisons with photographical archive of Chame (1988), material compiled at the laboratory, and alimentary content analysis. They were identified as Homo sapiens $\mathrm{L}$. ( $\mathrm{n}=49$ samples), Felidae $(\mathrm{n}=96)$, Myrmecophagidae $(n=2)$, Cervidae $(n=3)$, Taiassuidae $(n=7)$, Caviidae $(\mathrm{n}=25)$, Echimyidae $(\mathrm{n}=15)$. In five samples the zoological origin could not be determined.

The coprolites were rehydrated in aquous solution of trissodium phosphate (Callen \& Cameron 1960) and after $72 \mathrm{~h}$ a spontaneous sedimentation technique was used (Lutz 1919). The alimentary remains and the sediments were stored in Raillet and Henry solution in individual vials, and sent to the Laboratory of Ixodides, IOC-Fiocruz, to search for mites.

First, each sample of alimentary remains and sediments were placed individually on Petri dishes and examined under a stereomicroscope. Mites were permanently mounted in Hoyer's medium before examination. The slides were heated at $60^{\circ} \mathrm{C}$, their edges closed with a sealing wax, and placed in a sterilizer to dry. The specimens were examined under an optic microscope. The ticks that remained in the screens during the filtering process were mounted in Canada balsam after the treatment in phenol and creosote (Amorim \& Serra-Freire 1995).

Initially, Acari identification was made according to Krantz (1978) and Woolley (1988), and complemented by specific literature for each group found, as follows: Clifford and Anastos (1960), Webb et al. (1990), Amorim and SerraFreire (1999) (Ixodidae); Hirst (1917), Flechtmann (1986), Fain et al. (1990) (Astigmata), Lindquist (1969) (Actinedida), Balogh $(1961,1965)$, Balogh and Balogh (1988) (Oribatida).

\section{RESULTS}

In the total of coprolites samples examined, 50 mites were recovered; 13 from Homo sapiens coprolites; 32 from Felidae coprolites; three from Caviidade coprolites; one from Cervidae coprolites and one from a coprolite of unknown zoological origin.

Order Ixodida - The four larvae of ticks identified as Amblyomma Koch, 1844, when compared among them, demonstrated different morphological features, allowing us to state that they belong to two different species (Amblyomma sp.1 and Amblyomma sp. 2) (Figs 1, 2). However, they differ morphologically from the ones included in the identification key proposed by Amorim and SerraFreire (1999). Two larvae were identified as Ixodes sp. Latreille, 1795 (Fig. 3). Two scutum with eyes (Fig. 4), a gnathosoma with dentition formula 2:2 (Fig. 5), and a larval idiosoma with festoons and eyes (Fig. 6) were also recovered. These fragments belong to ticks of the Ixodidae family because of the presence of scutum and the gnathosome morphology. All these specimens and fragments were recovered from Felidae coprolites.

Order Gamasida - Three specimens of this order occurred in Homo sapiens coprolites (Fig. 7a). The presence of a pair of lateroventral stigmatal openings at the level of coxae III-IV associated with elongate peritremes made the identification possible (Fig. 7b). However, due to the poor preservation of these specimens, we could not go further in the identification.

Order Astigmata - Two adult specimens (Fig. 8a) of the suborder Acaridia and one larva (Fig. 8b) were found. The adult specimens were collected from Homo sapiens coprolites, and the larva was only from Felidae. Two Anoetidae hypopodes (Fig. 9) were recovered from Felidae coprolites. Two specimens of the family Atopomelidae were recovered. One of them was a female of Chirodiscoides caviae Hirst, 1917 (Fig. 10) and the other, a female exuviae (Fig. 11). Both of them were from Felidae coprolites. Several mites of the family Acaridae were found. Five of them were identified as Suidasia pontifica Oudemans, 1905 (Fig. 12), collected from Homo sapiens, Felidae and Caviidae coprolites. Another seven mites of this family were recovered from coprolites of the same zoological origin and from one coprolite of unknown zoological origin. One specimen of the family Glycyphagidae, recovered from Felidae coprolite, was identified as a female of Blomia tropicalis Bronswijck, Cock and Oshima, 1973 (Fig. 13). One specimen of the family Pyroglyphidae was identified as a male of Hirstia passericola Hull, 1931 (Fig. 14), from Felidae coprolite.

Order Actinedida - Two specimens of the family Tarsomenidae, a female fragment (Fig. 15), from Felidae coprolite, and a female of Iponemus radiatae (Lindquist and Bedard, 1961)(Fig. 16), from Cervidae coprolite.

Order Oribatida - Mites of this order were identified as Apolohmannia Aoki, 1960 (Fig. 17); Aphelacarus Grandjean, 1932 (Fig. 18); Pterobates Balogh and Mahunka, 1977 (Fig. 19); Eohypochthonius sp. Jacot, 1938 (Fig. 20); Cosmochthonius Berlese, 1910, (Fig. 21) similar to C. lanatus foveolatus Beck, 1962. This last genus was the most numerous considering the amount of exuviae found (Fig. 22) in comparison to the others genus that 

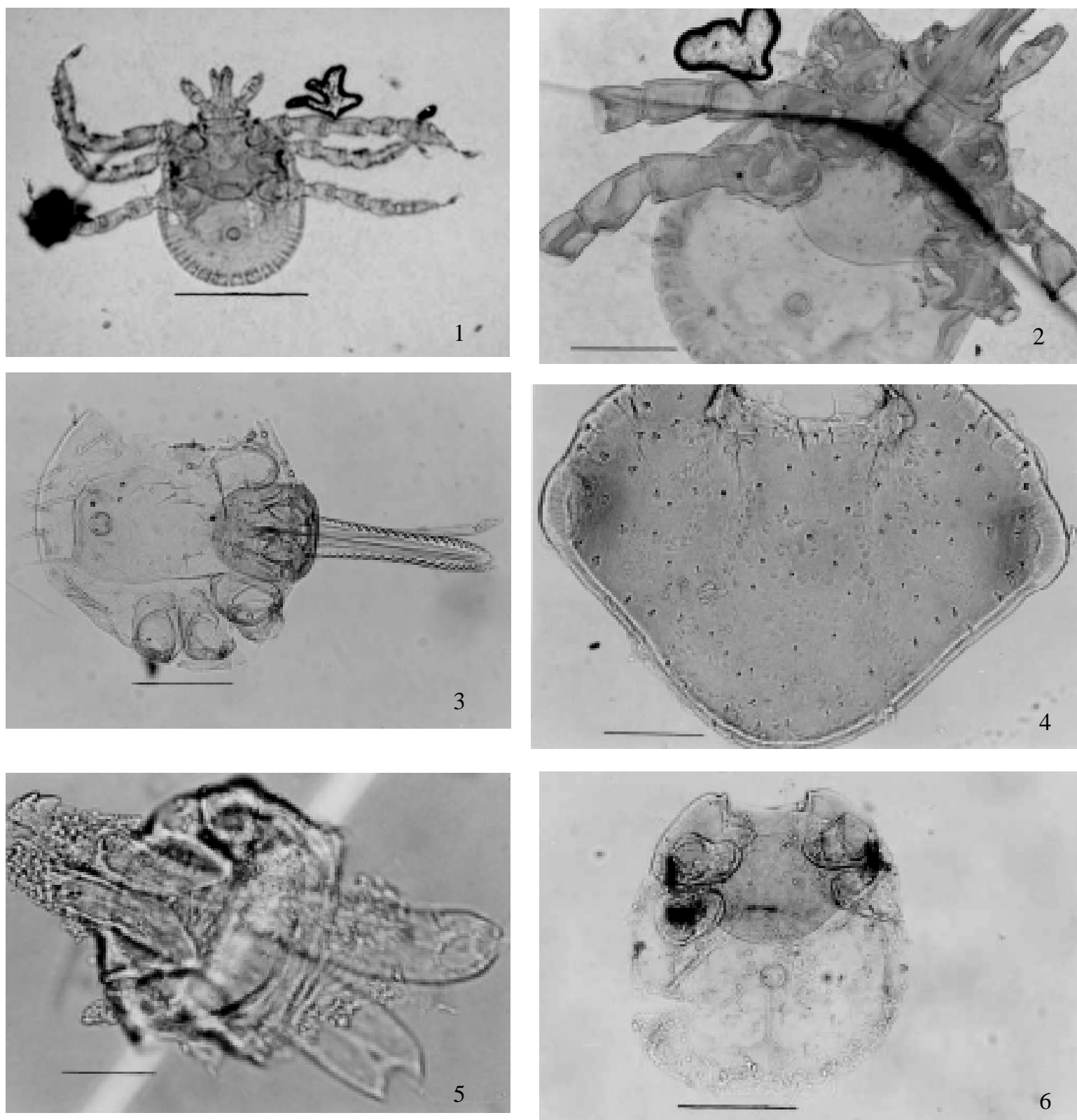

Fig. 1: Amblyomma sp.1 (bar $=500 \mu \mathrm{m})$. Fig. 2: Amblyomma sp. $2($ bar $=200 \mu \mathrm{m})$. Fig. 3: Ixodes sp. $($ bar $=200 \mu \mathrm{m})$. Fig. 4: scutum of ixodid tick $($ bar $=200 \mu \mathrm{m})$. Fig. 5: gnathosoma of ixodid tick $($ bar $=200 \mu \mathrm{m})$. Fig. 6: idiosoma of larva of ixodid tick $($ bar $=200 \mu \mathrm{m})$
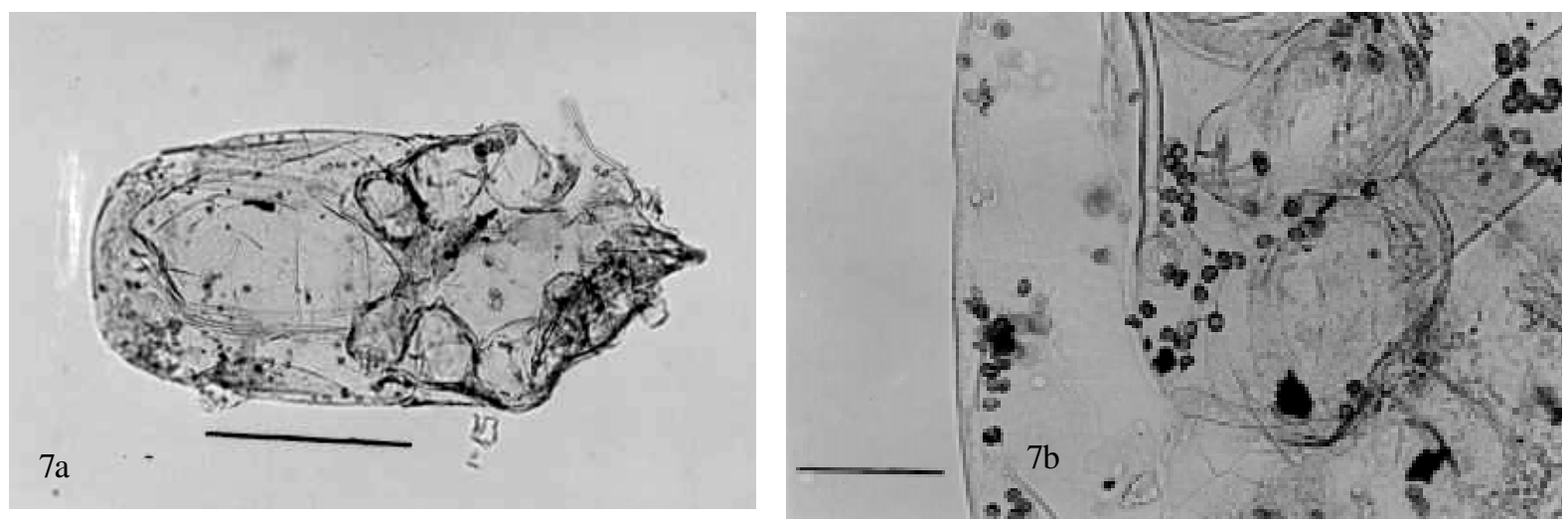

Fig. 7: order Gamasida - a: gamasid mite $(\mathrm{bar}=200 \mu \mathrm{m})$; b: stigmatal opening associated with elongate peritreme $(\mathrm{bar}=50 \mu \mathrm{m})$ 

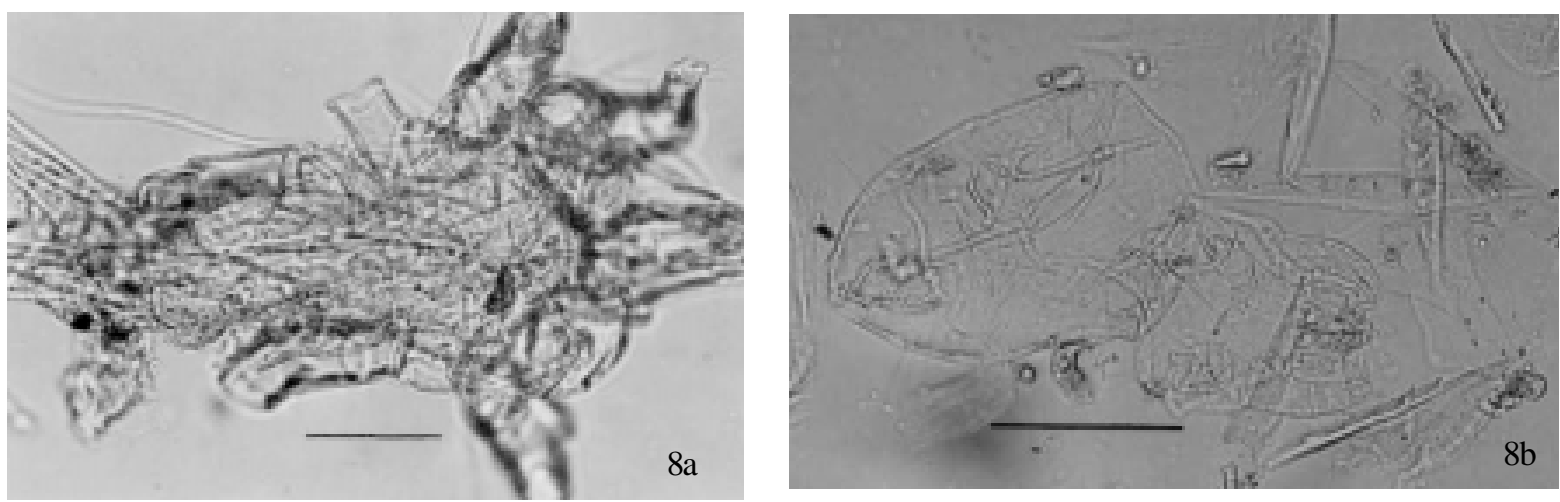

Fig. 8: mites of the suborder Acaridia - a: adult $($ bar $=200 \mu \mathrm{m})$; b: larva $($ bar $=200 \mu \mathrm{m})$
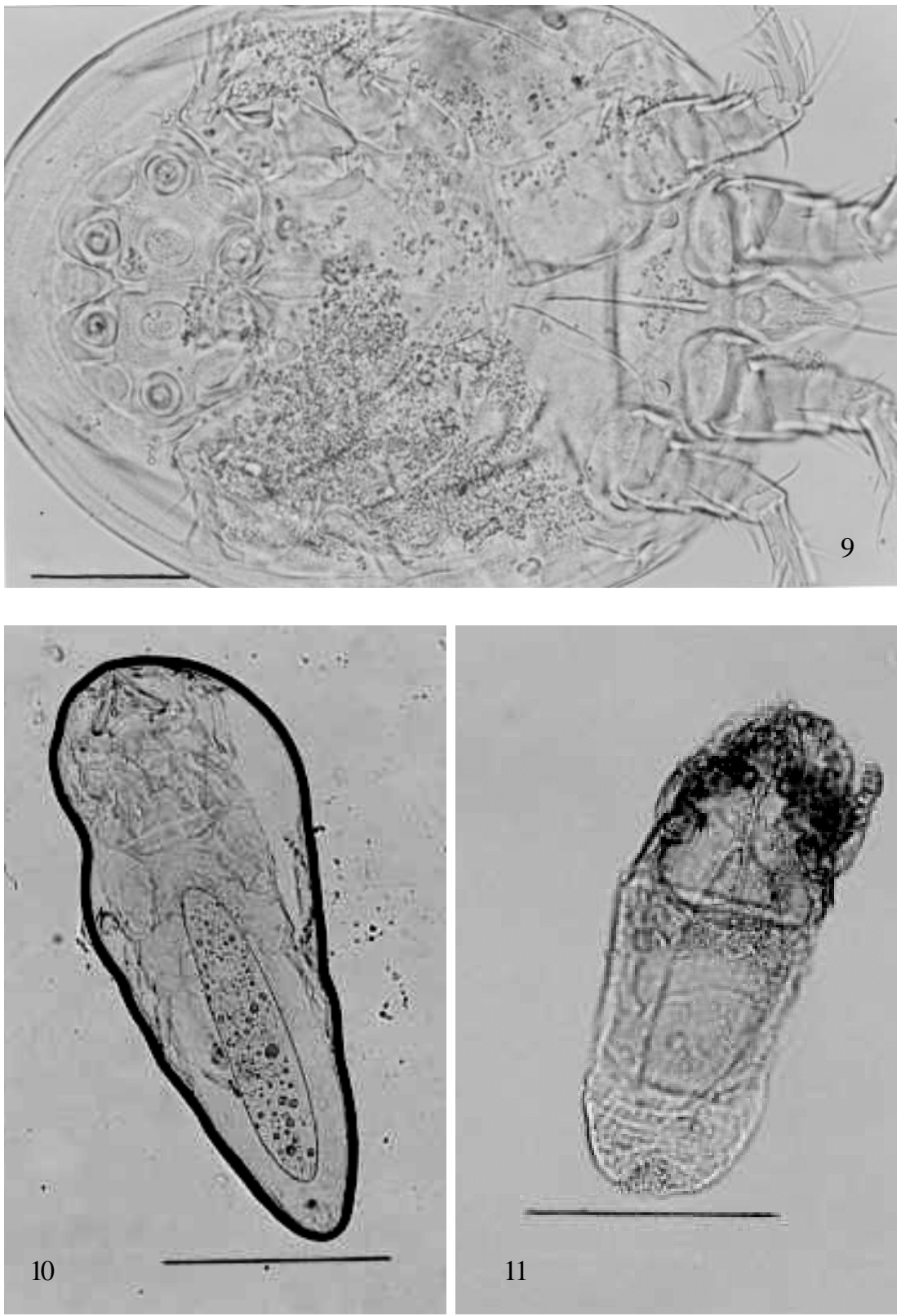

Fig. 9: hypopus of the family Anoetidae (bar $=50 \mu \mathrm{m}$ ). Fig. 10: Chirodiscoides caviae. Female (bar $=200 \mu \mathrm{m})$. Fig. 11: exuviae of atopomelid mite $(\mathrm{bar}=200 \mu \mathrm{m})$ 

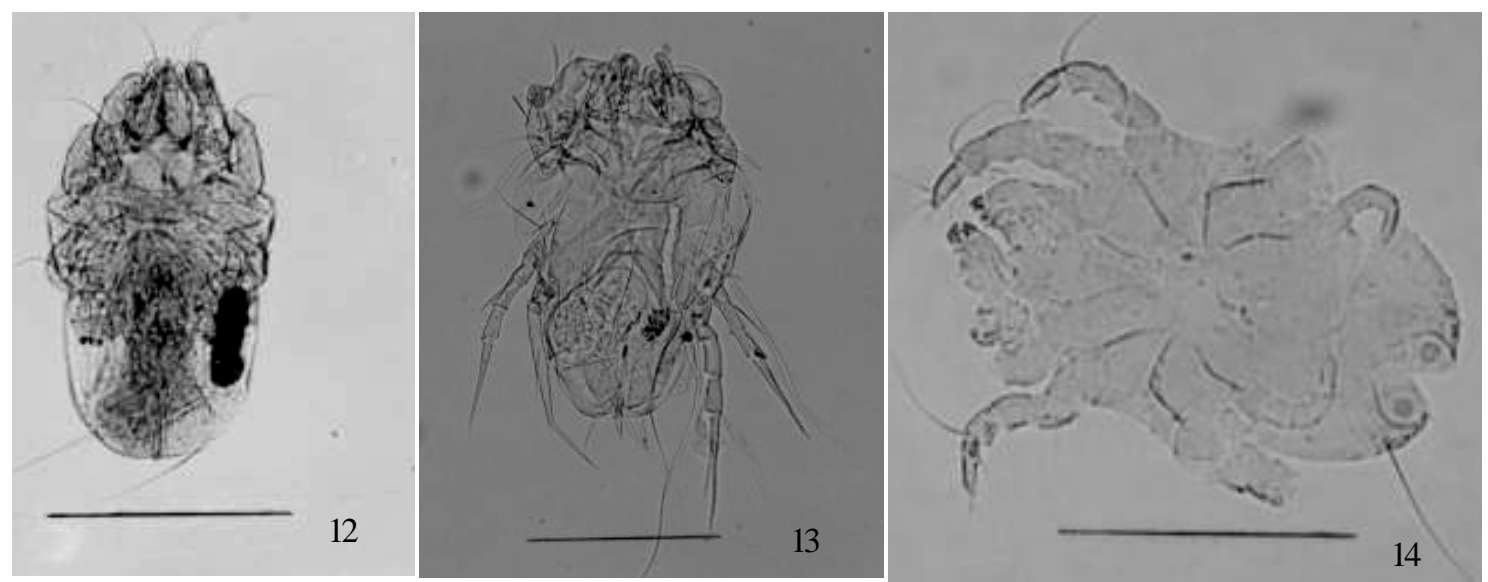

Fig. 12: Suidasia pontifica. Male $(\mathrm{bar}=200 \mu \mathrm{m})$. Fig. 13: Blomia tropicalis. Female $(\mathrm{bar}=200 \mu \mathrm{m})$. Fig. 14: Hirstia passericola . Male $($ bar $=200 \mu \mathrm{m})$
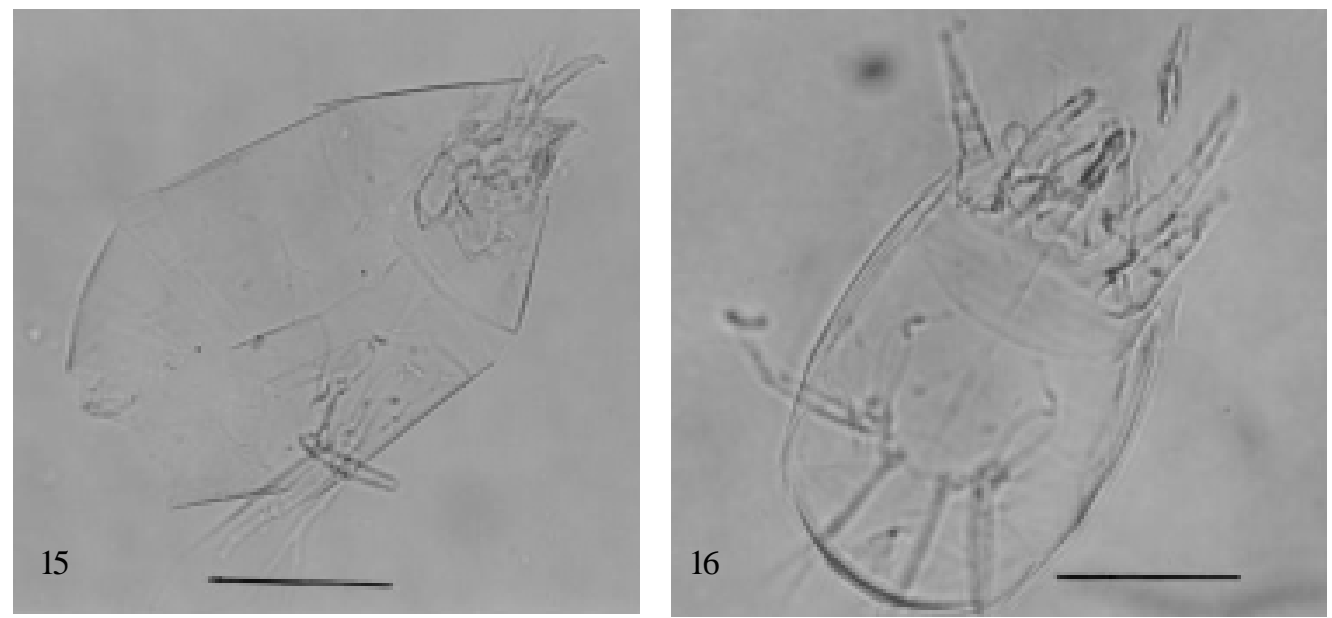

Fig. 15: fragment of mite of the family Tarsonemidae. Female $(\mathrm{bar}=50 \mu \mathrm{m})$. Fig. 16: Iponemus radiatae. Female $(\mathrm{bar}=50 \mu \mathrm{m})$

were represented by one specimen. One specimen of the Poronoticae group with pteromorphae not auriculate was also recovered. All specimens from this order were collected from Felidae coprolites, except for the seven exuviae of Cosmochthonius that were from Homo sapiens coprolites.

\section{DISCUSSION}

Ticks are arthropods, and are obligate blood feeders on mammals, reptiles, and birds. They may cause injury to their hosts through exsaguination, secondary infection, irritation at the attachment sites, or through the transmission of disease organisms (Krantz 1978). Ticks serve as reservoirs and vectors for viruses, bacteria, sporozoa (Krantz 1978), rickettsias (Lemos et al. 1977a,b), and spirochaetes (Yoshinari et al. 1997). They also have been observed to produce motor paralysis (Serra-Freire 1983).

The larvae of Amblyomma and Ixodes, the scutum, gnathosoma, and larval idiosoma, were recovered from $\mathrm{Fe}$ lidae coprolites. We suppose that they were ingested with the felid prey since in the archaeological site, coprolites of animals of the families Myrmecophagidae, Taiassuidae, Cervidae, Caviidae and Echimyidae were also examined.
Moreover, Lima (1991) observed that in this archaeological site, food supply was obtained through the hunting of small and medium sized animals around 9,000 yr BP and 2,000 yr $\mathrm{BP}$, respectively. Therefore, these animals occurred in the region and they are possible prey for felids.

Species of Amblyomma have already been reported biting humans (Famadas et al. 1997, Lemos et al. 1997a,b) as well as those of the genus Ixodes (Webb et al. 1990). Some species of these genera are confirmed vectors of bioagents (Webb et al. 1990, Schaffner \& Standaert 1996, Lemos et al. 1997a,b). These larvae could be carrying a disease agent for their hosts. The observations above are in agreement with those of Persing et al. (1990), who detected the presence of Borrelia burgdorferi DNA in museum tick specimens, and Poinar (1995), who suggested that argasid fossil ticks could be carrying a primitive spirochete to their hosts.

The finding of ticks in archaeological material can give rise to investigations in human and animal remains to detect the presence of organisms transmitted by them and address the possible antiquity of certain tick-borne diseases. 
The presence of ixodid ticks at Furna do Estrago, reveals the possibility of exposure of the ancient human population to tick-borne diseases.

The majority of gamasid mites are free-living but many species are ecto and endoparasites of reptiles, birds and mammals, or invertebrates (Krantz 1978, Woolley 1988). The specimens of this order were found in Homo sapiens coprolites, indicating that they could have been carried to the feces by other arthropods, possibly those associated with vegetal tissues observed by Lima (1991) at the human burials. They also could be present in the coprolites since they are soil and feces predators.

Mites of the family Tarsonemidae are, in large part, associated with other arthropods (Krantz 1978). This is the case of Iponemus species, which prey on the eggs of bark beetles and live as commensals in beetle galleries
(Lindquist \& Bedard 1961). Considering the biological behavior of this genus, the most probable hypothesis is that the mite invaded the coprolites after defecation.

Anoetid hypopodes are common on insects and other arthropods but are also frequent inhabitants of humid and organic substrates (Krantz 1978). The presence of a sucker plate observed in the specimens collected indicates that they belong to species associated with insects. Therefore, the hypopodes found in Felidae coprolites probably were carried to the fresh feces by coprophilic insects. This hypothesis is in agreement with the observations of Radovksy (1970) who explained the finding of Anoetidae hypopodes in human coprolites.

Members of the family Atopomelidae are ectoparasites of mammals (Krantz 1978, Oconnor 1982). The specimens recovered from Felidae coprolites, were probably
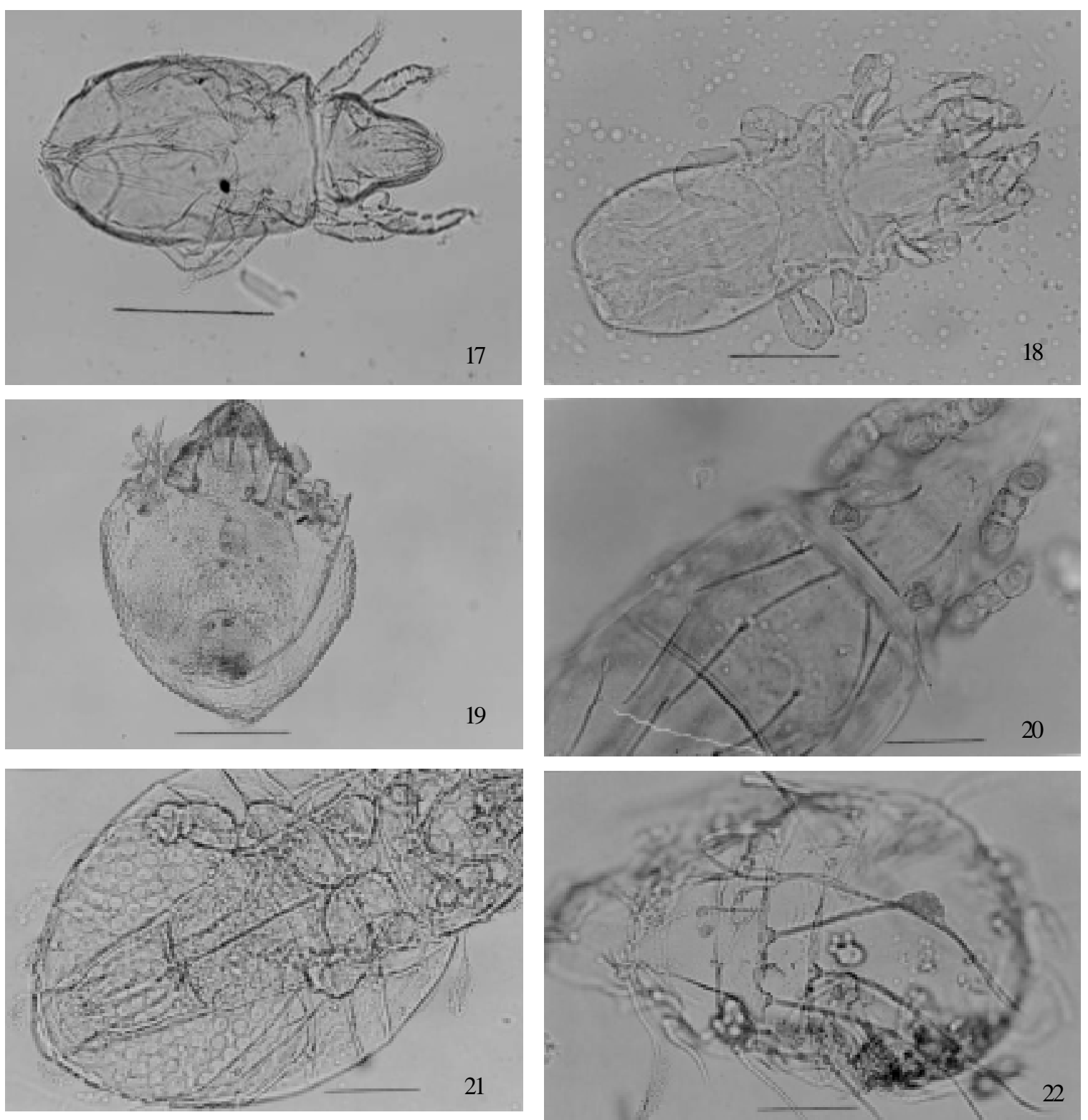

Fig. 17: Apolohmannia sp. $($ bar $=200 \mu \mathrm{m})$. Fig. 18: Aphelacarus sp. $($ bar $=50 \mu \mathrm{m})$. Fig. 19: Pterobates sp. $($ bar $=200 \mu \mathrm{m})$. Fig. 20 : Eohypochthonius sp. $($ bar $=200 \mu \mathrm{m})$. Fig. 21: Cosmochthonius sp. $($ bar $=50 \mu \mathrm{m})$. Fig. 22: exuviae of Cosmochthonius $\mathrm{sp} .(\mathrm{bar}=200 \mu \mathrm{m})$ 
ingested with the felid prey. Most probably a rodent prey since coprolites of Caviidae and Echimyidae were also found at the archaeological site. In addition, the alimentary contents of the felid coprolites had hairs and bone fragments. Invasion of the sample after defecation can be rejected, since these mites are permanent ectoparasites.

The species Chirodiscoides caviae is a common parasite of guinea pigs and has already been reported in Cavia porcellus L., C. cobaya Erxleben, 1777 and Galea leucoblephara Meyen, 1832 (Fain 1979). In Brazil, Flechtmann et al. (1974) reported for the first time in the state of São Paulo, the occurrence of this mite species. We are now reporting its occurrence in the state of Pernambuco.

Considering the specificity of atopomelid mites to their hosts, we suppose that the archaeological site of Furna do Estrago was occupied by caviid rodents as proved by the finding of $C$. caviae.

Most of the species of the family Pyroglyphidae are nest inhabitants, being more numerous in bird nests than in mammal nests (Oconnor 1982, Fain et al. 1990). Other species occur in stored products and house dust (van Bronswijk \& Sinha 1971). Therefore, according to Fain et al. (1990), it seems that the nests of birds are the true habitat of these mites, and the domiciliary environment was secondarily invaded by pyroglyphids from passeriform birds.

The finding of a pyroglyphid mite indicates that the climate in the study region was humid and temperate, since van Bronswijk and Sinha (1971) observed that these mites seem to be more abundant in these areas. In fact, the environment was more humid in Furna do Estrago around 2,000 yr BP (Lima 1991).

The importance of the pyroglyphid mites appears to lie in their ability to induce respiratory allergies (van Bronswijk \& Sinha 1971).

The genus Hirstia has been reported in nest of birds (Solarz 1995, Bhattacharyya 1999), and in house dust (Colloff 1998). This genus was recovered from a Caviidae coprolite and suggests an association with rodent nests. However, we did not find any references about this fact in the literature consulted. Since it has already been reported in house dust, we suppose that it has reached human dwellings through birds and/or rodents.

The family Glycyphagidae comprises a large group associated with nests of small mammals, especially of rodents (Flechtmann 1986). Many lineages invaded stored products (Oconnor 1982) but are also present in house dust (Wooley 1988, Colloff 1998).

Species of Blomia are well represented in stored products and Oconnor (1982) suggests that this genus is originally from South America, as evidenced by its abundance and ubiquity in house dust of the neotropical region. The finding of $B$. tropicalis in the archaeological site of Furna do Estrago corroborates with this assumption due to the antiquity of the studied material.

B. tropicalis is very abundant in tropical and subtropical regions. The climatic conditions in these regions, with mean annual temperature of $28^{\circ} \mathrm{C}$ and mean relative humidity of $82 \%$, offer a good environment for the growth of this species (Mariana et al. 1996). These observations indicate that the climate in the region was humid and temperate as observed for pyroglyphid mites.

In this work, B. tropicalis was recovered from Felidae coprolites. Probably it was associated with small mammal nest and was ingested by the felid.

According to Colloff (1998) in essence, the pyroglyphids were originally bird-nest dwellers but underwent a shift in habitat to the human nest around the time of the first human settlement, associated with agricultural production, some 10,000 years ago. The glycyphagid inhabitants of human dwellings made a habitat shift from nests of small mammals and likewise encountered similarities with homes, with food resources in the form of seeds, cereals, and other plant materials. Given similarity of trophic niches of human dwellings to those available naturally, it is not surprising that a number of mite species have become associated with human habitations. On basis of the above observations, we can suppose that the actual characterization of some pyroglyphid and glycyphagid species living in anthropic environment has passed through an adaptation period of these mites and their hosts to a sinanthropic environment. This adaptation could have occurred when the subsistence conditions concerning dietary resources in the region become more suitable to human occupation. This fact, according to Lima (1991) occurred between 1,000 and 2,000 yr BP in the archaeological site of Furna do Estrago. The fauna attested by bone artifacts points out a more humid environment that was more favourable to human occupation than the one exploited by the hunter-gatheres around 9,000 yr BP

The Acaridae is a large assemblage of saprophagus, graminivorous, fungivorous and phytophagus species which are frequently found as contaminants of stored and processed food (Krantz 1978). However, they are not restricted to these habitats since they are also found as nidicoles of vertebrates, nidicoles of insects, and in other remains such as organic material, carrion, dung, and decaying matter.

Mites of the species Suidasia pontifica were recovered from Homo sapiens, Felidae and Caviidae coprolites. The most probable hypothesis is that they were carried to fresh feces by coprophilic insects. This supposition is in accordance with the observations of Radovsky (1970) to explain the presence of Acaridae tritonymph in human coprolites and of Kliks (1988) who suggested that the astigmatid mites found in human mummies are ancient or recent pos-mortem invaders.

A similar argument for pyroglyphid and glycyphagid mites could be proposed for species of Suidasia, since they had already been reported in bird nests (Bhattacharyya 1999), and could have substituted their natural habitat by sinanthropic and anthopic habitat. This could have happened as a consequence of human lifestyle favoring the colonization of this mite species. At the present, S. pontifica is more frequently reported as contaminants of stored and processed food (Ho 1996, Sanchez-Borges et al. 1997, Olsen 1998) and at house dust (Galvão \& Guitton 1986, Montealegre et al. 1997, Chew et al. 1999). 
The importance of species of the families Pyroglyphidae, Glycyphagidae and Acaridae as allergens causing allergic diseases is noteworthy. This public health hazard is getting worse throughout the years and it is now considered a severe problem of modern humans. Continual investigations in archaeological material will bring, in the future, information about these mites' species allowing the understanding of their interaction with human beings.

From the oribatid mites recovered, the genus Apolohmannia and Aphelacarus had not yet been reported for the neotropical region (Balogh \& Balogh 1988), however, Corvarrubias and Toro (1997) reported the species Aphelacarus acarinus in Chile for the first time. The present work confirms the neotropical distribution of this mite species. The genus Apolohmannia was reported in Japan (Balogh 1965). This is the first report of Aphelacarus in Brazil and of Apolohmannia at the American continent.

The species Pterobates incertus was reported in the state of Rio de Janeiro (Balogh \& Balogh 1988). Now we are including the state of Pernambuco in the geographical distribution of this species. The genus Eohypochthonius was previously reported to North America and Circumtropical region (Balogh 1961, 1965), and is now reported in Brazil.

The genus Cosmochthonius was previously reported in Europe, Java and neotropical region (Balogh 1961), and the species $C$. lanatus foveolatus in Chile (Corvarrubias $\&$ Toro 1997). We confirm the neotropical distribution of this species and report it for the first time in Brazil.

Corvarrubias and Toro (1997) studied oribatid species in Chile and concluded that $A$. acarinus and $C$. lanatus foveolatus constitute the dominant fauna in ecosystems of prolonged dryness. According to Lima (1991) at the archaeological site of Furna do Estrago, the archaeological evidence reflects rigorous climate conditions - high temperatures and dryness for a long period of time, between 9,000 and 8,000 yr BP This fact is consistent with the finding of these two species of mites.

The findings of Apolohamnnia, Pterobates, Eohypochthonius, Cosmochthonius and Aphelacarus are indicative that the neotropical climate with humidity and temperature compatible with the development of these genera was established in the region of the archaeological site.

Members of all the families of the order Oribatida with remains that are known as fossils are still living at the present time. This is indicative of the exceptionally low rates of morphogenesis in Oribatida. Apparently, the cause of the low variability level in Oribatida lies in the stability of the soil as an environment as well as in the diversity of ecological niches available (Krivolusky \& Druk 1986). These are the features that explain why a number of extremely archaic forms have survived to the present time. The preliminary results about the finding of oribatid mites in archaeological material reported by Guerra et al. (2001a) and the ones presented in this paper corroborate the observations mentioned above.

Oribatid species and species assemblages offer several advantages for assessing the quality of terrestrial ecosystems (Behan-Pelletier 1999). Therefore they could be used as bioindicators, and in this way help to reconstruct the environment conditions of the past as already demonstrated with other arthropods. Atkinson et al. (1987) reconstructed seasonal temperatures in Britain during the past 22,000 years using radiocarbon-dated beetle remains. Some soil animals, especially those with firm exoskeletons, such as the oribatids, have tendency to fossilize (Krivolusky \& Druk 1986) and their remains could be used for the same purpose.

Finally, it is worth mentioning that the genus and species recovered in the present study still exist. We suppose that human action has favored the colonization of domiciliary environments by mites previously associated with animals bringing, as a result, undesired consequences to human beings. This change in habitat could have happened from the moment that human groups become more sedentary. In the archaeological site of Furna do Estrago the diversity and amount of food sources allowed human settlement, population growth, and cultural complexity around 2,000 yr BP (Lima 1991). The population exploited simultaneously the sources of the "caatinga" and of the "mata serrana do Buriti" that made possible a semi-sedentary way of life and a hunting-gathering economy (Lima 1991). This way of life made possible for the population at Furna do Estrago to interact with the region's animals and plants, and consequently with their mites.

\section{ACKNWLEDGEMENTS}

To Dr Sheila Maria Ferraz Mendonça de Souza from Escola Nacional de Saúde Pública-Fiocruz, Rio de Janeiro and Dr Jeannete Maria Dias de Lima (in memoriam) from Universidade Católica de Pernambuco, Recife, for the information about the archaeological site and for sending the samples.

\section{REFERENCES}

Amorim M, Serra-Freire NM 1995. Morfologia do estádio de larva de Amblyomma rotundatum. Parasitol Dia 19: 9-19.

Amorim M, Serra-Freire NM 1999. Chave dicotômica para identificação de larvas de algumas espécies do gênero Amblyomma Koch, 1844 (Acari: Ixodidae). Entomol Vect 6: 75-90.

Araújo A, Ferreira LF, Guidon N, Serra-Freire NM, Reinhard K, Dittamar K 2000. Ten thousand years of head lice infection. Parasitol Today 16: 269.

Araújo A, Santos MC, Confalonieri U, Ribeiro B M Ferreira LF 1986. Mumificações naturais na pré-história brasileira: um estudo de caso. Rev Arqueol 3: 32-39.

Astos ECC, Leguia PG, Wheeler J 1999. Identificación de ectoparasitos de mil años de antigüedad provenientes de Alpacas e Llamas momificadas de la cultura Chiribaya-Alto Tardio. In XIV Congresso Latinoamericano de Parasitologia, Acapulco, Guerrero, México, p. 114.

Atkinson TC, Briffa KR, Coope GR 1987. Seasonal temperatures in Britain during the past 22,000 years, reconstructed using beetle remains. Nature 325: 587-592.

Balogh J 1961. Identificatin keys of world oribatid (Acari) families and genera. Acta Zool Acad Sci Hung 7: 243-344.

Balogh J 1965. A sinopsis of the world oribatid (Acari) genera. Acta Zool Acad Sci Hung 11: 5-99.

Balogh J, Balogh P 1988. Oribatid Mites of the Neotropical Region I. Zoosystematical and Ecological Institute, Eötvos Lorand University Budapest, Elsevier Science Publishers, Hungary, $335 \mathrm{pp}$.

Behan-Pelletier VM 1999. Oribatid mite biodiversity in 
agroecosystems: role for bioindication. Agric Ecosyst Environ 74: 411-423.

Bhattacharyya S 1999. New records of arthropods associated with the bird's nests in India. Environ Ecol 17: 685-692.

Bresciani J, Haarlov N, Nansen P, Moller G 1983. Head louse (Pediculus humanus subsp capitis deGeer) from mummified corpses of Greenlanders, A.D. 1460 ( \pm 50). Acta Entomol Fenn 42: 24-27.

Buckland PC, Sadler JP 1989. A biogeography of the human flea, Pulex irritans L. (Siphonaptera: Pulicidae). J Biogeogr 16: $115-120$.

Callen EO, Cameron TWM 1960. A prehistoric diet revealed in coprolites. New Sci 7: 35-40.

Chame M 1988. Estudo Comparativo das Fezes e Coprólitos Não Humanos da Região Arqueológica de São Raimundo Nonato-Sudeste do Piauí, MSc Thesis, Universidade Federal do Rio de Janeiro, Rio de Janeiro, 134 pp.

Chew FT, Zhang L, Ho TM, Lee BW 1999. House dust mite fauna of tropical Singopore. Clin Exp Allergy 29: 201-216.

Clifford CM, Anastos G 1960. The use of chaetotaxy on the identification of larval ticks (Acarina: Ixodidae). J Parasitol 46: $567-578$.

Colloff M J 1998. Taxonomy and identification of dust mites. Allergy 53 (Suppl. 48): 7-12.

Covarrubias R, Toro H 1997. Espécies de oribatida (Acarina, Cryptostigmata) asociada a espécies de plantas, em quebradas com vegetación de neblina de la província de Antofasta, Chile. Acta Entomol Chil 21: 13-33.

Ewing HE 1924. Lice from human mummies. Science 60: 389390.

Fain A 1979. Les Listrophorides d'Amerique neotropicale, (Acarina, Astigmates). II Familie Atopomelidae. Bull Inst $R$ Sci Nat Belg 51: 1-158.

Fain A, Guerin B, Hart BJ 1990. Mites and Allergic Disease, B Guerin Allerbio, Virginia, 190 pp.

Famadas KM, Lemos ERS, Coura JR, Machado RD, SerraFreire NM. 1997. Amblyomma cooperi (Acari:Ixodidae) parasitando humano em áreas de foco de febre maculosa, São Paulo. In V Congresso Ibérico de Parasitologia, II Congresso Português de Parasitologia e X Congresso Español de Parasitologia, Portugal, p. 114.

Flechtmann CHW 1986. Ácaros em Produtos Armazenados e na Poeira Domiciliar, Universidade de São Paulo, Piracicaba, $97 \mathrm{pp}$.

Flechtmann CHW, Zamith APL, Confalonieri UEC, Nuernberg S 1974. Sobre três ácaros parasitos de animais de laboratório. Arq Univ Fed Rural Rio de Janeiro 4: 29-34.

Galvão AB, Guitton N 1986. Ácaros em poeira domiciliar das capitais brasileiras e ilha de Fernando de Noronha. Mem Inst Oswaldo Cruz 81: 417-430.

Girling MA 1984. Eighteenth century records of human lice (Pthiraptera, Anoplura) and fleas (Siphonaptera, Pulicidae) in the city of London. Entomol Mon Mag 120: 207-210.

Gothe R, Schöl H 1994. Deer keds (Lipoptena cervi) in the accompanying equipament of the Late Neolithic human mummy from the Similaun, South Tyro. Parasitol Res 80: 81-83.

Guerra RMSNC, Duarte AN, Gazêta GS, Ferreira LF, SerraFreire NM 2001a. Mites associated with coprolites from the archaeological site of Furna do Estrago, Pernambuco state, Brazil. Entomol Vect 8: 463-479.

Guerra RMSNC, Duarte AN, Oliveira HH, Mello RP, SerraFreire NM 2001b. The finding of Felicola felis (Mallophaga: Trichodectidae) and exuviae of Amblycera in Felidae coprolites from the archaeological site of Furna do Estrago, Pernambuco state, Brazil. Entomol Vect 8: 395-402.

Hirst S 1917. On three parasitic acari. An Mag Nat Hist 20: 431434.
Ho TM 1996. First report of Suidasia pontifica (Acari: Acaridae) in milk powder. Southeast Asian J Trop Med Public Health 27: 853-854.

Horne P 1979. Head lice from an Aleutian mummy. Paleopathol Newsl 25: 7-8.

Kenward H 1999. Pubic lice (Pthirus pubis L.) were present in Roman and Medieval Britain. Antiquity 73: 911-915.

Kliks M McK 1988. Paleoparasitological analysis of fecal material from Amerindian (or New World) mummies: evaluation of saprophytic arthropod remains. Paleopathol Newsl 64: 7-11.

Krivolutsky DA, Druk A Ya 1986. Fossil oribatid mites. Ann Rev Entomol 31: 533-545.

Krantz GWA 1978. A Manual of Acarology, 2nd ed., Oregon State University Book stores, Corvallis, 489 pp.

Lane RS, Poinar Jr GO 1986. First fossil tick (Acari: Ixodidae) in New World amber. Int J Acarol 12: 75-78.

Lemos ERS, Machado RD, Coura JR, Guimarães MAA, SerraFreire NM, Amorim M, Gazêta GS 1997a. Epidemiological aspects of the Brazilian spotted fever: seasonal activity of ticks collected in na endemic área in São Paulo, Brazil. Rev Soc Bras Med Trop 30: 181-185.

Lemos ERS, Machado RD, Pires FCA, Costa LMC, Coura JR 1997b. Rickettsiae-infected ticks in an endemic area of spotted fever in the state of Minas Gerais, Brazil. Mem Inst Oswaldo Cruz 92: 477-481.

Lima JMD 1991. Dois períodos de subsistência no agreste pernambucano: 9.000 e 2.000 anos. Clio-Rev Arq Univ Fed Pernambuco 4: 57-61.

Lindquist EE 1969. Review of Holartic tarsonemid mites (Acarina: Prostigmata) parasitizing eggs of ipine bark beetles. Mem Ent Soc Can 60: 3-111.

Lindquist EE, Bedard W D 1961. Biology and taxonomy of mites of the genus Tarsonemoides (Acari: Tarsonemidae) parasitizing eggs of bark beetles of the genus Ipis. Can Entomol 93: 982-998.

Lutz A 1919. O Schistosoma mansoni e a shistosomatose segundo observações feitas no Brasil. Mem Inst Oswaldo Cruz 11: 121-155.

Mariana A, Ho TM, Heah SK 1996. Life-cycle, longevity and fecundity of Blomia tropicalis (Acari: Glycyphagidae) in a tropical laboratory. Southeast Asian J Trop Med Public Health 27: 392-395.

Montealegre F, Sepulveda A, Bayona M, Quinones C, Fernandez-Caldas E 1997. Identification of the domestic mite fauna of Puerto Rico. P R Health Sci J 16: 109-116.

Mumcuoglu YK, Zias J 1988. Head lice, Pediculus humanus capitis (Anoplura: Pediculidae) from hair combs excavated in Israel and dated from the first century B.C. to the eighth century A.D. J Med Entomol 25: 545-547.

Oconnor BM 1982. Evolutionary ecology of astigmatid mites. Ann Rev Entomol 27: 385-409.

Olsen AR 1998. Regulatory action criteria for filth and other extraneous materials. II. Allergenic mites: an emerging food safety issue. Regul Toxicol Pharmacol 28: 190-198.

Persing DH, Telford SR, Rys PN, Dodge DE, White TJ, Malawista SE, Spielman A 1990. Detection of Borrelia burgdorferi DNA in museum specimens of Ixodes dammini ticks. Science 249: 1420-1423.

Poinar Jr GO 1995. First fossil soft ticks, Ornithodoros antiquus n. sp. (Acari: Argasidae) in Dominican amber with evidence of their mammalian host. Experientia 51: 384-387.

Radovsky F 1970. Mites associated with coprolites and mummified human remains in Nevada. Archaeol Res Fac 10: 186-190.

Rick F, Dittmar K, Reinhard K, Rocha GC, Ferreira LF, Araújo 
A 2001. Lice infection in prehistoric population of Atacama desert, Chile. J Bras Patol 37 (Supl.): 187.

Sadler JP 1990. Records of ectoparasites on humans and sheep from Viking-age deposits in the Former Western Settlement of Greenland. J Med Entomol 27: 628-631.

Sanchez-Borges M, Capriles-Hulett A, Fernandez-Caldas E, Suarez-Chacon R, Caballero F, Castillo S, Sotillo E 1997. Mite-contaminated foods as cause of anaphylaxis. $\mathrm{J} \mathrm{Al}$ lergy Clin Immunol 99: 738-743.

Schaffner W, Standaert SM 1996. Ehrlichiosis-in pursuit of an emerging infection. N Engl J Med 334: 262-263.

Serra-Freire NM 1983. Tick paralysis in Brazil. Trop Hlth Prod 15: $124-126$.
Solarz K 1995. Fauna and biology of the Pyroglyphidae of Poland. Wiad Parazytol 41: 343-353.

van Bronswijk JEMH, Sinha RN 1971. Pyroglyphid mites (Acari) and house dust allergy. J Allergy 47: 31-51.

Webb JP, Bennett Jr SG, Challet GL 1990. The larval ticks of the genus Ixodes Latreille (Acari: Ixodidae) of California. Bull Soc Vector Ecol 15: 73-124.

Woolley T A 1988. Acarology: Mites and Human Welfare, Wiley, New York, 484 pp.

Yoshinari NH, Barros PJL, Bonoldi VLN, Ishikawa M, Battesti DMB, Pirana S, Fonseca AH, Schumaker TT 1997. Perfil da borreliose de Lyme no Brasil. Rev Hosp Clin Fac Med S Paulo 52: 111-117. 